\title{
Prevalence of Renal Tuberculosis in Patients With Chronic Renal Failure Prior to Dialysis, Associated with Constitutional Symptoms
}

\author{
Mona Hosny
}

\author{
General Medicine Department \\ Ain-Shams University
}

\section{Abstract}

20 patients with chronic renal failure, not yet on dialysis, were included in the study. They were all females. They were divided into 2 groups according to etiology of renal failure:

- Group (1): 10 patients with chronic renal failure due to diabetic nephropathy as D.M. is a predispasing factor for TB. Mean age of this group was $(54.5 \pm 9.1)$ years.

- Group (2) : 10 patients with chronic renal failure due to membrano - proliferative glomerulonephritis as it is the most common cause in Egypt for renal failure. Their mean age was $(50.9 \pm 8.4)$ years.

These 2 groups were compared with a third group of 10 normal controls.

Constitutional and urogenital symptoms were a guide to choose patients included in the study. For all patients the following was done:

Complete urine analysis, Acid-Fast Bacilli (AFB) in urine; Tuberculin test, chest X-Ray, Plain urinary tract, CT of (Kidneys - ureter - bladder) and PCR of Mycobacterium Tuberculosis in urine using Gen-Probe Amplification test.

We found 4 patients out of 10 (40\%) were positive for renal TB in Group (1), 3 patients out of $10(30 \%)$ were positive for renal TB in Group (2), using PCR and other tests mentioned above.

Prevalence rate of renal tuberculosis in group (1) is $40 \%$ and $30 \%$ in group (2) with a total of $35 \%$ in both groups, which cannot be ignored as a high prevalence rate in this study.

We conclude that Diabetes Mellitus is a risk factor for renal Tuberculosis, but also chronic renal insufficiency in itself is another risk factor but to a lesser extent than DM.

There was no significant statistical difference between chronic renal insufficiency due to diabetic nephropathy and chronic renal insufficiency due to membrano proliferative glomerulonephritis as regards renal Tuberculosis which was detected essentially by PCR of TB in urine.

Compared to normal group, there were significant statistical differences in all parameters that were measured, between normal group and the other two groups together and separately.

\section{Introduction}

Tuberculosis (TB) is an ancient disease that had almost been forgotten in developed countries since an effective bactericidal chemotherapy was developed in the 1940s. The prevalence and incidence of the disease showed a dramatic decline during the past several decades in western countries. However, 


\section{Mona Hosny}

over the last few years, there has been a rising trend in the incidence of T.B. all over the world. (Kang-Ju. et al., 2001).

Patients with chronic renal failure have an increased incidence of tuberculosis (T.B.) compared to those with normal renal function, which may be due to a decrease in cellular immunity. Previous studies have found T.B. to be predominantly extrapulmonary in chronic renal failure patients (Simon et al., 2001).

The genitourinary system is the most common site of extra - pulmonary tuberculosis. Renal tuberculosis almost always results from an initial pulmonary infection (Kawashima et al., 1997).

One of the main obstacles to the effective control of tuberculosis is the long time taken from laboratory diagnosis by culture. On the other hand, acid-fast microscopy, although rapid enough to provide a result within $24 \mathrm{hrs}$, lacks sensitivity and is unable to distinguish tubercle bacilli from other mycobacteria (Wang et al., 1999).

Several PCR tests have now been developed for the detection of Mycobacterium tuberculosis (MTB) in clinical specimens (Bonington et al., 2000).

The lower limit of detection reported by PCR varies between 1 and 100 bacilli (Bennedson J. et al., 1996).

PCR has proven useful for the direct diagnosis of TB by allowing use of diverse genetic elements as the target templates (GAMBOA et al., 1997).

\section{Patients And Methods}

20 patients with chronic renal failure prior to dialysis were included in the study. They were chosen from Nephrology Department , Ain-Shams University. They were divided into two groups according to the etiology of chronic renal failure - Group 1 included 10 patients with chronic renal failure due to diabetic nephropathy and group 2 included 10 patients with chronic renal failure insufficiency due to membranoproliferative glomerulonephritis. A third group of ten healthy controls was included in the study.

So we have 3 groups in the study :

- Group 1: 10 patients with diabetic nephropathy and chronic renal failure prior to dialysis.

- Group 2: 10 patients with membrano-proliferative glomerulonep hritis and chronic renal failure prior to dialysis.

- Group 3: 10 healthy normal controls.

Patients of Group 1 were included in a group by itself because Diabetes mellitus constitutes a risk factor for T.B.

Patients of Group 2 were chosen from those having chronic renal failure due to membranoproliferative glomeru lonephritis as it constitutes one of the common causes of renal failure .

For all patients and controls, the following was done:

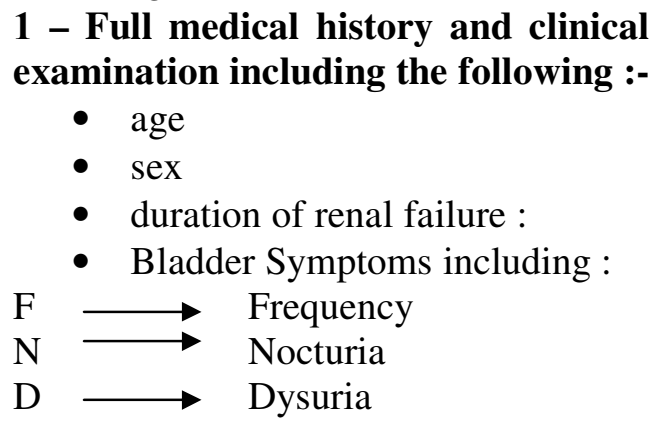

(These constitute bladder inflammatory symptoms).

- Renal Colic or loin pain

- Constitutional symptoms including :

$\mathrm{W} \rightarrow$ Weight Loss $\mathrm{A} \rightarrow$ Anorexia

$\mathrm{F} \rightarrow$ Fever $\quad \mathrm{M} \rightarrow$ Malaise

$\mathrm{N} \rightarrow$ Night sweats

2 - Complete urine analysis including

White blood cells $\rightarrow$ WBCs 


\section{Prevalence of Renal Tuberculosis in Patients}

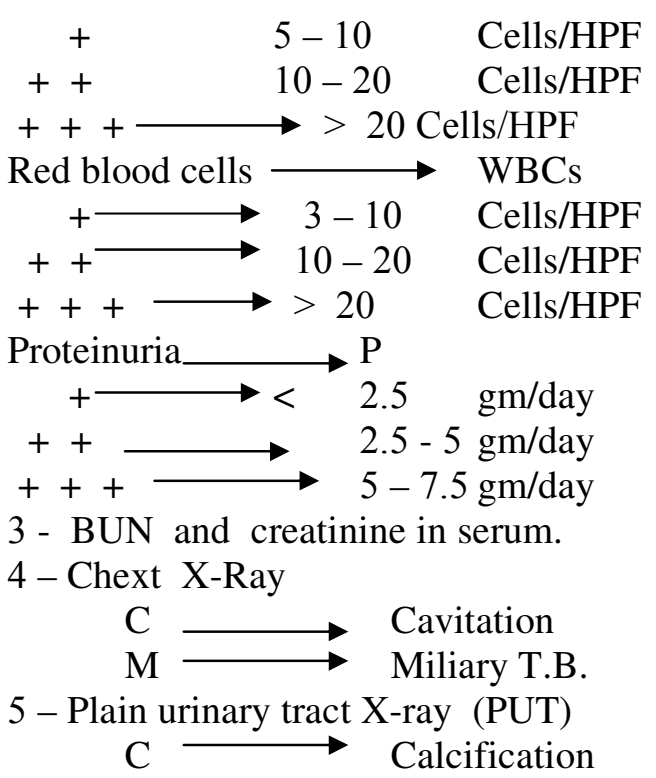

6 - Computerized Axial Tomography

(CAT scan) of Kidneys: in our study, it is superior to pyelography :

$\mathrm{M} \longrightarrow$ Moth - eaten appearance of minor calyces (early sign)

$\mathrm{D} \rightarrow$ dilatation of pelvicaly ceal system (more advanced sign).

Other signs such as cavities and bladder wall thickening were not present in our study.

7 - Acid - Fast Bacilli (AFB) in urine.

8 - Tuberculin Test.

9 - Polymerized Chain Reaction (PCR)

for Tuberculosis in urine.

\section{Methods}

Complete urine analysis, BUN and creatinine were done by conventional methods in Ain-Shams University Hospital laboratories.

- Chest X-ray and Plain urinary Tract. X-ray were done in Radiology Department, Ain-Shams University.

- Computerized Axial Tomography was done in CT center, Ain-Shams University.

- Bacteriological examination for Acid-Fast Bacilli in urine was done by collecting three early morning urinary $\longrightarrow$ specimens on three suecessite days. Urine samples were centrifuged to obtain deposits. Acid-Fast Bacilli were detected by examination of urine deposits stained by Ziehl-Nelsen stain .

- Tuberculin test of the skin (Purified Protein Derivative [P.P.D.] Skin Testing).

1CC of Purified Protein Derivative of T.B. was injected intradermally in the skin and the wheal formed by the reaction was measured after 24 hours. If the wheal diameter was more than 10 $\mathrm{mm}$, it is positive. If more than that, it is strongly positive.

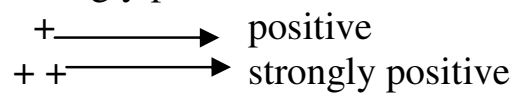

- Polymerized Chain Reaction (PCR) for Tuberculosis in urine was done by the Amplified Mycobacterium Direct Test (AMTDT). (Gen - Probe Inc., San-Diago, Calif.).

AMTDT is based on the isothermal amplification of target rRNA by DNA Intermediates followed by chemiluminiscent detection of amplicons with an Acridinium esterlabelled DNA probe. The AMTDT is highly sensitive and specific for detecting $M$. Tuberculosis. The sensitivity of the modified AMTDT using $500 \mu \mathrm{L}$ of sediment was $95 \% \underline{\text { \& }}$ the specifity was $100 \%$.

\section{Method Details:}

Urine samples were taken in early morning and stored at $4{ }^{\circ} \mathrm{C}$ prior to processing. Urine specimens were centrifuged at $3.600 \mathrm{x}$ g for $20 \mathrm{mn}$. The samples were digested and decontaminated with sodium dodecyl (Lauryl) sulfate (SDS) - $\mathrm{NaOH}$.

The sediment obtained was washed with $30 \mathrm{ml}$. of distilled water and centrifuged $(3.300 \mathrm{x} \mathrm{g}$. for $20 \mathrm{~min})$ and the 


\section{Mona Hosny}

supernatant was removed. For all specimens, half of sediment was stored at $-80^{\circ} \mathrm{C}$ for the Target - Amplified Test and the other half was used for Acid-Fast staining.

The AMTDT was performed with $500 \mu \mathrm{L}$ of pretreated (SDS-NaOH) specimen according to manufacturer's package insert. Each run-included positive and negative Amplification controls and positive and negative hybridization controls. A positive cutoff of 30.000 relative light units was used. All specimen were retested with $500 \mu \mathrm{L}$ of the same decontaminant sample.

\section{Results}

Results were included in 9 tables : - Table (1) : statistical comparison of group (1) and group (2) as regards history and symptoms.

- Table (2) : statistical comparison of group (1) and group (2) as regards laboratory results.
- Table (3) : statistical comparison of group (1) and group (2) as regards radiological findings.

- Table (4) : statistical comparison of group (1) and group (3) as regards history and laboratory results.

- Table (5) : statistical comparison of group (1) and group (3) as regards radiological findings.

- Table (6) : statistical comparison of group (2) and group (3) as regards history and laboratory results.

- Table (7) : statistical comparison of group (2) and group (3) as regards radiological findings.

- Table (8) : statistical comparison of laboratory results and radiological findings of PCR +ve patients with renal insufficiency in both groups (1) and (2) and group 3.

- Table (9) : statistical comparison of laboratory results and radiological findings of PCR +ve patients with renal insufficiency in group (1) and (2).

Table(1): Statistical comparison of Group (1) and Group (2) as regards history $s$ and symptoms.

\begin{tabular}{|l|l|l|l|}
\hline & Group (1) & Group (2) & P-value \\
\hline $\begin{array}{l}\text { Age (Means } \pm \text { SD) } \\
\text { In years }\end{array}$ & $54.5 \pm 9.1$ & $50.9 \pm 8.4$ & N.S. \\
\hline Sex (\%) ) & $100 \%$ O+ & $100 \%$ O+ & N.S. \\
\hline $\begin{array}{l}\text { Duration of renal failure in } \\
\text { years (mean } \pm \text { SD) }\end{array}$ & $5.8 \pm 3.0$ & $6.4 \pm 3.7$ & N.S. \\
\hline $\begin{array}{l}\text { Constitutional } \\
\text { Symptoms }\end{array}$ & & & \\
$\begin{array}{l}\text { Fever (\%) } \\
\text { Night Sweats (\%) }\end{array}$ & $80 \%$ & $100 \%$ & N. S. \\
Anorexia (\%) & $30 \%$ & $20 \%$ & N. S. \\
\hline $\begin{array}{l}\text { Bladder Symptoms } \\
\text { Frequency (\%) }\end{array}$ & $90 \%$ & $100 \%$ & N. S. \\
Nocturia & & $40 \%$ & P $<.005$ \\
Dlysuria & $90 \%$ & $30 \%$ & P $<.005$ \\
\hline Renal Colic (\%) & $80 \%$ & $40 \%$ & N.S. \\
\hline
\end{tabular}


Table (2) : Statistical comparison of group (1) and group (2) as regards laboratory results

\begin{tabular}{|c|c|c|c|}
\hline & Group (1) & Group (2) & P-Value \\
\hline $\begin{array}{l}\text { Urine Analysis } \\
\text { Proteinuria (\%) } \\
\text { W B Cs }(\%) \\
\text { R B Cs }(\%)\end{array}$ & $\begin{array}{r}100 \% \\
100 \% \\
50 \% \\
\end{array}$ & $\begin{array}{r}100 \% \\
100 \% \\
80 \% \\
\end{array}$ & $\begin{array}{l}\text { N.S. } \\
\text { N.S. } \\
P<.005\end{array}$ \\
\hline $\begin{array}{c}\text { BUN (Means } \pm \text { SD) } \\
\text { In mg/dl }\end{array}$ & $121.7 \pm 34.3$ & $110.3 \pm 42.8$ & N. S. \\
\hline $\begin{array}{l}\text { Creatinine (mean } \pm \text { SD)in } \\
\text { mg/dl }\end{array}$ & $7.5 \pm 2.0$ & $5.3 \pm 2.6$ & $\mathrm{P}<.05$ \\
\hline AFB in urine (\%) & $20 \%$ & $10 \%$ & $\mathrm{P}<.005$ \\
\hline Tuberculin Test (\%) & $10 \%$ & $10 \%$ & N.S. \\
\hline $\begin{array}{l}\text { PCR Tuberculosis } \\
\text { In urine ( \% ) }\end{array}$ & $40 \%$ & $30 \%$ & $\mathrm{P}<.05$ \\
\hline
\end{tabular}

Table (3) : Statistical comparison of group (1) and group (2) as regards Radiological imaging .

\begin{tabular}{|l|l|l|l|}
\hline & Group (1) & Group (2) & P-Value \\
\hline Chest X-Ray (\%) & $0 \%$ & $0 \%$ & N. S \\
\hline $\begin{array}{l}\text { Plain X-Ray of } \\
\begin{array}{l}\text { Urinary Tract } \\
\text { Calcification \% }\end{array}\end{array}$ & $10 \%$ & $0 \%$ & P $<.005$ \\
\hline $\begin{array}{l}\text { CT of Kidneys : } \\
\text { Moth eaten } \\
\text { appearance (\%) }\end{array}$ & $30 \%$ & $30 \%$ & N. S. \\
\hline Dilatation (\%) & $10 \%$ & $20 \%$ & P $<.005$ \\
\hline
\end{tabular}

Table (4) : Statistical comparison of group (1) and group (3) as regards history and laboratory results

\begin{tabular}{|l|l|l|l|}
\hline & Group (1) & Group (3) & P-Value \\
\hline $\begin{array}{l}\text { Age (meant } \pm \text { SD) } \\
\text { In years }\end{array}$ & $54.5 \pm 9.1$ & $36.2 \pm 13.1$ & $\mathrm{P}<.0001$ \\
\hline Sex (\%) & $100 \%$ O+ & $100 \%$ O+ & $\mathrm{N} . \mathrm{S}$. \\
\hline Creatinine (mean + SD) & $7.5 \pm 2.0$ & $.71 \pm .39$ & $\mathrm{P}<.0001$ \\
\hline $\begin{array}{l}\text { Urine analysis } \\
\text { Proteinuria (\%) }\end{array}$ & $100 \%$ & -- & $\mathrm{P}<.0001$ \\
$\begin{array}{l}\text { WBCs (\%) } \\
\text { RBCs (\%) }\end{array}$ & $100 \%$ & -- & $\mathrm{P}<.0001$ \\
\hline $\begin{array}{l}\text { AFB in urine } \\
(\% \text { of positive cases) }\end{array}$ & $50 \%$ & -- & $\mathrm{P}<.0001$ \\
\hline $\begin{array}{l}\text { Tuberculin Test } \\
\text { (\% of positive cases) }\end{array}$ & $20 \%$ & -- & $\mathrm{P}<.005$ \\
\hline $\begin{array}{l}\text { PCR Tuberculosis } \\
\text { In urine } \\
(\% \text { of positive cases) }\end{array}$ & $10 \%$ & -- & $\mathrm{P} .005$ \\
\hline
\end{tabular}


Table (5) : Statistical comparison of Group ( 1 ) and group (3) as regards radiological findings.

\begin{tabular}{|l|l|l|l|}
\hline & Group (1) & Group (3) & P-Value \\
\hline $\begin{array}{l}\text { Chest X-Ray } \\
(\% \text { of positive cases ) }\end{array}$ & $0 \%$ & $0 \%$ & N. S. \\
\hline $\begin{array}{l}\text { Plain X-ray of } \\
\text { urinary tract } \\
\text { Calcification (\%) }\end{array}$ & $10 \%$ & -- & $\mathrm{P}<.005$ \\
\hline $\begin{array}{l}\text { CT of Kidney } \\
\text { Motheaten } \\
\quad \begin{array}{l}\text { Appearance (\%) } \\
\text { Dilation (\%) }\end{array}\end{array}$ & $30 \%$ & -- & $\mathrm{P}<.0005$ \\
\hline
\end{tabular}

Table (6) : Statistical comparison of group (2) and Group (3) as regards history and laboratory results

\begin{tabular}{|l|l|l|l|}
\hline & Group (3) & Group (3) & P-Value \\
\hline $\begin{array}{l}\text { Age (meant } \pm \text { SD) } \\
\text { In years }\end{array}$ & $50.9 \pm 8.4$ & $36.2 \pm 13.1$ & $\mathrm{P}<.0001$ \\
\hline Sex (\%) & $100 \%$ O+ & $100 \%$ O+ & $\mathrm{N} . \mathrm{S}$. \\
\hline $\begin{array}{l}\text { Creatinine (mean } \pm \text { SD) } \\
\text { In mg/dl }\end{array}$ & $5.3 \pm 2.6$ & $.71 \pm .39$ & $\mathrm{P}<.0001$ \\
\hline $\begin{array}{l}\text { BUN ( mean } \pm \text { SD) } \\
\text { in mg/dl }\end{array}$ & $110.3 \pm 42.8$ & $21.5 \pm 3.5$ & $\mathrm{P}<.0001$ \\
\hline $\begin{array}{l}\text { Urine analysis } \\
\text { Proteinuria (\%) }\end{array}$ & $100 \%$ & -- & $\mathrm{P}<.0001$ \\
$\begin{array}{l}\text { WBCs (\%) } \\
\text { RBCs (\%) }\end{array}$ & $100 \%$ & -- & $\mathrm{P}<.0001$ \\
\hline $\begin{array}{l}\text { AFB in urine } \\
(\% \text { of positive cases) }\end{array}$ & $80 \%$ & -- & $\mathrm{P}<.0001$ \\
\hline $\begin{array}{l}\text { Tuberculin Test } \\
(\% \text { of positive cases) }\end{array}$ & $10 \%$ & -- & $\mathrm{P}<.001$ \\
\hline $\begin{array}{l}\text { PCR Tuberculosis in urine } \\
(\% \text { of positive cases) }\end{array}$ & $30 \%$ & -- & $\mathrm{P}<.001$ \\
\hline
\end{tabular}

Table (7) : Statistical comparison of Group ( 2 ) and group (3) as regards radiological findings.

\begin{tabular}{|l|l|l|l|}
\hline & Group (2) & Group (3) & P-Value \\
\hline $\begin{array}{l}\text { Chest X-Ray } \\
(\% \text { of positive cases ) }\end{array}$ & $0 \%$ & $0 \%$ & N. S. \\
\hline $\begin{array}{l}\text { Plain X-ray of } \\
\text { urinary tract } \\
\text { Calcification (\%) }\end{array}$ & $0 \%$ & $0 \%$ & N. S. \\
\hline $\begin{array}{l}\text { CT of Kidney } \\
\text { Motheaten } \\
\text { Appearance (\%) } \\
\text { Dilation (\%) }\end{array}$ & $30 \%$ & -- & $\mathrm{P}<.0001$ \\
& $20 \%$ & -- & $\mathrm{P}<.001$ \\
\hline
\end{tabular}




\section{Prevalence of Renal Tuberculosis in Patients}

Table (8) : Statistical comparison of laboratory results and radiological findings of PCR + ve patients in Group (1) and Group (2)

\begin{tabular}{|c|c|c|c|}
\hline & $\begin{array}{c}\text { Group (1) } \\
\text { (PCR +ve } \\
\text { patients) }\end{array}$ & $\begin{array}{c}\text { Group (2) } \\
\text { (PCR +ve patients) }\end{array}$ & $\begin{array}{c}\text { Total } \\
(\text { PCR +ve } \\
\text { patients })\end{array}$ \\
\hline $\begin{array}{c}\text { AFB in Urine } \\
(\% \text { of positive cases) }\end{array}$ & $50 \%$ & $33.3 \%$ & $42.8 \%$ \\
\hline $\begin{array}{l}\text { Tuberculin test } \\
\text { (\% of positive cases) }\end{array}$ & $25 \%$ & $33.3 \%$ & $28.5 \%$ \\
\hline $\begin{array}{l}\text { Urine analysis } \\
\text { - Proteinuria }\end{array}$ & & & \\
\hline$+\quad \longrightarrow(\%)$ & $100 \%$ & $100 \%$ & $100 \%$ \\
\hline$++\quad \longrightarrow(\%)$ & -- & -- & -- \\
\hline$\stackrel{++}{\bullet} \mathrm{W} \mathrm{B} \mathrm{Cs.}$ & -- & -- & -- \\
\hline$++\quad \longrightarrow(\%)$ & $75 \%$ & $100 \%$ & $85.7 \%$ \\
\hline$\stackrel{+++}{-} \underset{\mathrm{R} \mathrm{B} \mathrm{Cs}}{\longrightarrow}(\%)$ & $25 \%$ & -- & $14.2 \%$ \\
\hline$+\longrightarrow(\%)$ & $25 \%$ & $100 \%$ & $57.2 \%$ \\
\hline$++\quad \longrightarrow(\%)$ & $25 \%$ & -- & $14.2 \%$ \\
\hline $\begin{array}{l}\text { CT of Kidneys } \\
\text { (Disturbed \%) }\end{array}$ & $100 \%$ & $100 \%$ & $100 \%$ \\
\hline
\end{tabular}

Table (9) : Statistical comparison of laboratory results and radiological findings of PCR +ve patients with renal insufficiency in both groups (1) \& (2) and control group (3).

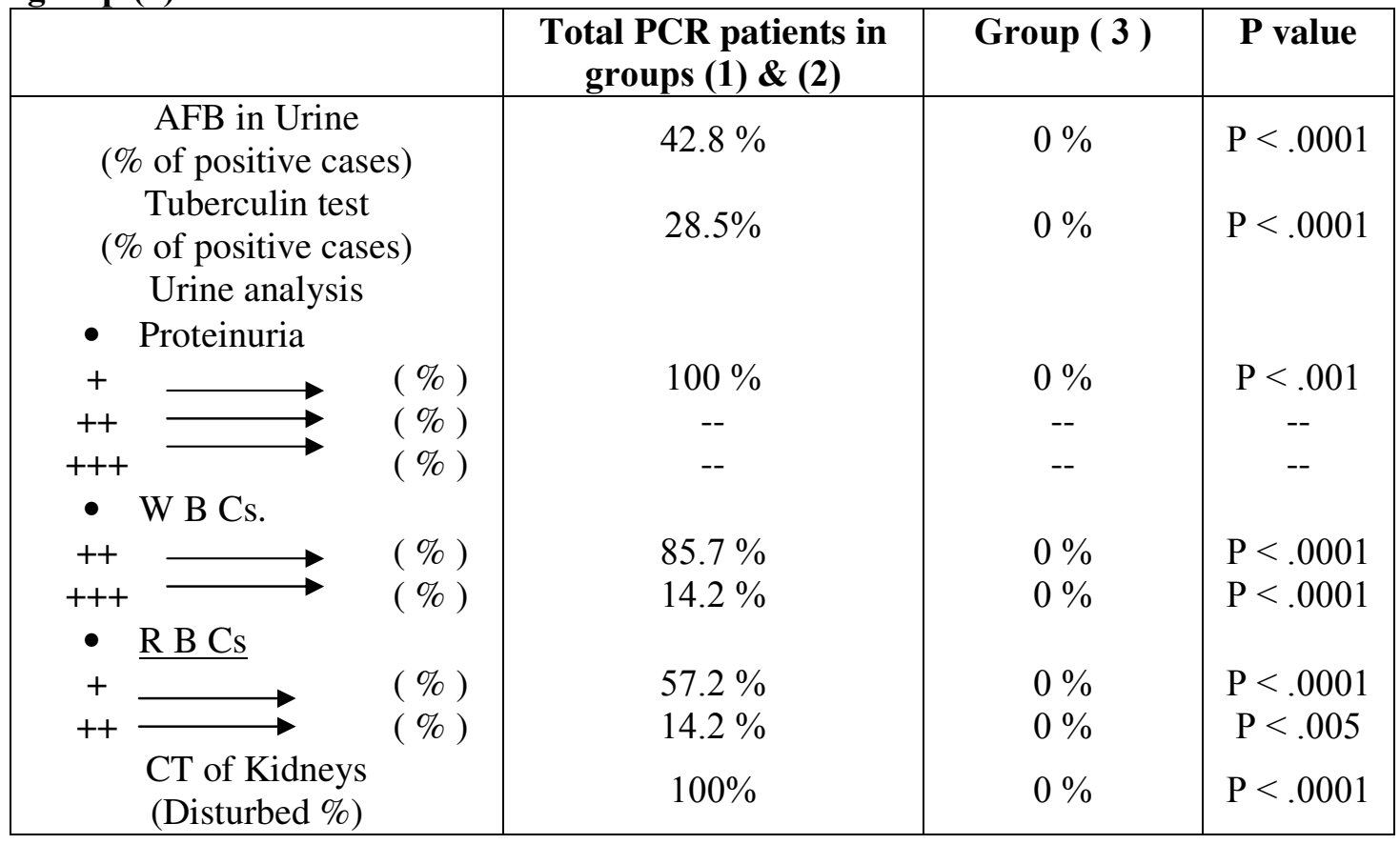




\section{Mona Hosny}

\section{Discussion}

In our study, 3 groups were included : Two groups consisting each of 10 patients with chronic renal failure prior to dialysis, and the third group was formed of 10 normal healthy controls.

Group 1: 10 patients with chronic renal failure due to diabetic nephropathy.

Group 2:10 patients with chronic renal failure due to membranoprolif erative glomerulonephritis.

Group 3 : control group consisting of 10 healthy persons.

In 1999, Al-Shoaib study was made on 80 patients with chronic renal failure, who were followed up for 3 years. $10 \%$ developed Tuberculosis. This study used Mantoux test, chest radiographs and sputum AFB to detect TB. $2 \%$ out of these $10 \%$ developed Renal Tuberculosis without previous renal disease. Detection of disease was delayed because of lack of constitutional symptoms.

In 1999, Al-Shoaib et al., made a 5 years retrospective study on chronic renal failure patients, 210 patients were included in the study. Screening for TB was made by Ziehl-Nelsen microscopy for AFB, and culture of specimens on Lowenstein Jensen media, radiological and histological examination. $5 \%$ of the study population had been diagnosed as having Tuberculosis: 3\% pulmonary $\mathrm{TB}$, and $2 \%$ extrapulmonary TB. Of these $5 \% \longrightarrow 47 \%$ of them were diabetic and the remaining 53\% were non-diabetic.

In our study, we have screened 20 patients with chronic renal failure prior to dialysis. The 20 patients were chosen of the same sex, being all female, to avoid sex differences. We have also chosen them of nearly the same decade of age in order to avoid changes accompanying changing of the age factor. We have chosen our patients having all of them constitutional symptoms as a cause for proceeding forwards to investigate TB presence. There were also urinary symptoms, which together with constitutional symptoms, were suggestive of presence of Renal Tuberculosis. They nearly all had some renal symptoms suggesting discomfort to a varying degree and in a varying percentage, being more in Group (1) as compared to Group (2). This suggests that Diabetic Nephropathy is an encouraging factor for Renal Tuberculosis $(\mathrm{P}<.005)$.

We have used routine complete urine analysis to detect patients who deserve being followed by other investigations to detect TB. Both proteinuria and pyuria were present in both groups (1) and (2) as compared with group $(3)(\mathrm{P}<.0001)$. There was not significant difference between group (1) and group (2). But there was a significant difference in presence of RBCs in urine between group (1) and group $(2)(\mathrm{P}<.005)$, being more in group (2). This may be due to the more inflammatory nature of membrano proliferative glomerulonephritis.

BUN and Creatinine levels showed no significant difference between Group (1) and Group (2).

We also used AFB screening in urine specimens as a screening method in which there was a significant difference between Group (1) and Group (2) $(\mathrm{P}<.005)$, being more in group (1). This may be due to the presence of diabetes as a risk factor encouraging a severe and open lesion discharging AFB in Group (1).

In our study, Plain chest X-Ray didn't show any significant data in the three groups.

Also, we have used Plain urinary tract X-ray which only has showed 


\section{Prevalence of Renal Tuberculosis in Patients}

positive data in one case in group (1). This was non significant, but it was showing calcification.

Waeitje et al., (1998), made their study on Tuberculin test on chronic renal failure patients. In this study, Tuberculin skin test was done to 307 patients, $32 \%$ were anergic. 48 out of 307 patients $(16 \%)$ had a positive Tuberculin skin test.

Smirmoff et al., (1998), found that $19 \%$ of their population study of chronic renal failure were Tuberculin reactors. In our study, 2 patients out of $20(10 \%)$ were positive for Tuberculin test. One patient was in group (1) and the other positive patient was in group (2). This means that the etiology of chronic renal failure doesn't play a role in Anergy to Tuberculin Test.

Kirchner et al., (2000), have used CT for diagnosing renal Tuberculosis. They reported a case of Renal Tuberculosis proven by culture. The patient had on Tom ography hypodense lesions clearly on the cortex border of Kidney. Other findings of Renal Tuberculosis as dilatation of Pelvica lyceal system and hydronephrosis were not seen at all and they postulated the finding as an early case of Renal Tuberculosis.

As regards early Moth-eaten appearance on $\mathrm{CT}$, in our study, 3 patients out of 10 in group (1) and 3 patients out of 10 in group (2) has shown it, which makes 6 patients out of $20(30 \%)$. Dilatation was only present in 1 case out of 10 in group (1) $(10 \%)$ and 2 cases out of 10 in group (2) (20\%) $(\mathrm{P}<.005)$. This means that cases were mostly in early stage when diagnosed, and this doesn't support the idea that DM encourages progress of Renal Tuberculosis.

Portillo - Gomez et al., (2002), studies 286 specimens by Ziel-Nelsen stain, culture on Lowenstein - Jensen stains and by PCR. PCR method was highly specific $100 \%$ to identify $\mathrm{M}$. Tuberculosis from a variety of extra pulmonary specimens including urine. Sensitivity of this test for urine was 93\%.

In the study of Wolska-Goska et al. (1998), culture negative and PCR positive results existed in 144 out of 278 patients.

Fontana et al., (1997), studied 95 patients for Tuberculosis by PCR. 35 patients were highly suspicious by symptoms \& other investigations than PCR. There were 38 positive PCR results.

In our study, we have also used PCR by Gen-Probe Amplification test. We found 4 patients out of 10 in group (1) being positive for TB by PCR and 3 patients out of 10 in group (2) being positive for TB by PCR. This means that $40 \%$ of group (1) and $30 \%$ of group (2) are positive for TB by PCR, with a total of 7 patients out of 20 patients with chronic renal failure, which means that $35 \%$ of patients with chronic renal failure are positive by PCR for TB.

In patients with positive PCR, we found the following :

\section{AFB in Urine of Patients with positive PCR:-}

$50 \%$ of patients with positive PCR for TB had positive Acid-Fast Bacilli in urine (AFB) in group (1). $33.3 \%$ of patients with positive PCR in group (2) had positive AFB in urine.

This means that diabetes encourages open Tuberculous lesions in Renal Tuberculosis. When the two groups (1) and (2), there is a total of $42.8 \%$ of patients with positive PCR for TB discharging AFB in urine, which is highly significant difference when compared to control group $(\mathrm{P}<.0001)$, who didn't show any evidence of positive AFB in urine. This 


\section{Mona Hosny}

means that Renal Tuberculosis in renal failure discharges a good amount of AFB in a considerable percentage of patients positive for TB by PCR as compared to normal $(\mathrm{P}<.0001)$. This also means that the remaining positive PCR patients for TB, didn't discharge AFB in urine in spite that they had detectable TB bacilli by PCR.

\section{Tuberculin test in positive PCR patients for $\mathbf{T B}$ :-}

$25 \%$ of positive PCR patients in group (1) with diabetic nephropathy had +ve Tuberculin test. 33\% of +ve PCR patients in group (2) with membranoproliferative GN had +ve Tuberculin test. This means anergy is more prevalent in diabetic patients with renal failure.

A total of group (1) and group (2) is $28.5 \%$ patients with chronic renal failure and positive PCR for TB in urine. These patients had positive Tuberculin test. This means that nearly one third of patients with +ve PCR for TB had +ve Tuberculin test and the remaining had anergy, which means that it is still a useful confirmatory test.

\section{Urine analysis in the positive PCR patients for TB in urine}

\section{a - Proteinuria :}

Proteinuria was present as mild degree in all patients of chronic renal failure and positive PCR test as compared to control group $(\mathrm{P}<.001)$. This means that renal Tuberculosis in chronic renal failure is mostly associated with mild proteinuria. b - Pyuria

Pyuria was present as moderate degree in $75 \%$ of patients of group (1) with positive PCR for TB and in 100\% of patients of group (2) with positive PCR for TB.

This makes a total of $85.7 \%$ of chronic renal failure patients with positive PCR for TB. This reflects the state of pyuria caused by renal
Tuberculosis, which must not be overlooked in patients with chronic renal failure.

Severe pyuria was only present in $25 \%$ of patients of group (1) and absent in group (2) with a total of $14.2 \%$ in chronic renal failure patients with positive PCR for TB in urine.

Both moderate and severe degree of pyuria showed highly significant difference between patients with chronic renal insufficiency and positive PCR test in one side and control group on the other side $(\mathrm{P}<.0001$ and $\mathrm{P}<$ $.005)$ respectively.

\section{c - Hematuria :}

Hematuria was present in mild degree in only $25 \%$ of group (1) and in $100 \%$ of group (2) which may reflect the more inflammatory nature of memb -ranoproliferative glomerulonephritis especially when accompanied by renal Tuberculosis.

A total of $57.7 \%$ of positive PCR patients with chronic renal failure had mild hematuria as an alarming sign for presence of TB.

Moderate degree of Hematuria was present in only $25 \%$ of group (1) and a total of $14.2 \%$ of chronic renal failure patients with positive PCR.

This means that moderate degree of hematuria is not a prevalent sign in renal Tuberculosis in patients with chronic renal failure prior to dialysis.

\section{4. d-Computerized \\ Axial \\ Tomography of kidney, ureter and bladder}

$100 \%$ of cases of chronic renal failure and positive PCR for $\mathrm{TB}$, had abnoremal CT for kidney, ureter and bladder, as compared to control group $(\mathrm{P}<.0001)$.

This means that $\mathrm{CT}$ is as reliable as PCR in diagnosing early and advanced changes in renal tuberculosis. So, CT is one of the essential tools for diagnosis of renal Tuberculosis. 


\section{Prevalence of Renal Tuberculosis in Patients}

\section{SUMMARY}

Diagnosis of Tuberculosis by PCR of Tubercle bacilli in urine is an important and efficient method of detecting renal Tuberculosis. This method can be supported by Computerized Axial Tomography of Kidney, ureter and bladder; AFB in urine and Tuberculin test.

Constitutional and renal symptoms are important. In chronic renal failure patients, the incidence of renal Tuberculosis is $40 \%$ among those due to diabetic nephropathy and in those due to membranoproliferative glomerulonep hritis, it is $30 \%$.

A totral of $35 \%$ in the two groups together are positive for PCR for renal Tuberculosis, making chronic renal insufficiency a good risk factor for renal Tuberculosis.

\section{References}

1. Al- Shoait, S.: Tuberculosis in chronic renal failure in Jeddah. Int. Urol. - Nephrol., 1999; 31 (4) : 571-575.

2. Bennedson J.; Thomson V.O.; Pfyffer G.E.; Punke G.; Feldmann B.A.; Antony J.P.; Heggin bothon M.; Fahr A., Hengstler M.; Cleator G. and Klapper P.: Utility of PCR in diagnosing pulmonary tuberculosis. Journal of Clinical Microbiology, 1996; June: 1407-1411.

3. Bonington A.; Strang J.I.G.; Klapper P.E.; Hood S.V.; Parish A., Swift P.J.; Damba J.; Stevens H.; Sawyer L.; Potgieter G.; Bailey A. and Wilkins E.G.L.: PCR in early diagnosis of Tuberculosis meningitis: Evaluation of the roche semi-automated COBAS Amplicor MTB-test with reference to the manual Amplicor MTB PC test . Tubercle and Lung Disease, 2000; 80 (415): 191-196.
4. Fontana D., Pozzi E., Porpiglia F., Galietti F., Morra I., Roc ca A. and Chirillo MG: Rapid identification of Mycobacterium Tuberculosis complex on urine samples by Gen-probe Amplification Test. Urol. Res., 1997; 25(6) : 391-394.

5. GAMBOA F., Manterello J.M.; Vinado B., Mata L., Giménez M., Lonca J., Manzano J.R., Rodrigo C., CARDOna P.J., Padilla E., Dominguez $J$. and Ausina V.: Direct detection of Mycobacterium Tuberculosis Complex in Nonrespiratory specimens by GenProbe Amplified Mycobacterium Tuberculosis Direct Test. Journal of Clinical Microbiology, 1997; Jan. Vol. 35, No. : 307 - 310.

6. Kang-Ju Chow, Hua-Chang Fang, Kuan-Jen Baï, Schang-Jyh Hwang, Ulu-Chang Yang and Msia-Min Chung: Tuberculosis in maintenance dialysis patients. Nephron, 2001; 88 : 138-143.

7. Kawashima A., Sandler CM, Goldman S.M., Rawal B.K., Fishman EK: CT of renal inflammatory disease. Radiographics, 1997; 17:851-866.

8. Kirchner T.M.; Kirchner J., Jacobi V.: Renale Parenchym defekte als Zeichem einer Nierentuber Kulose. (Renal Parenchymal defects as signs of renal Tuberculosis). Roentgenpr axis, 2000; 52 (10-12): 332-334.

9. Shohaib S.A., Scrimgeour E.M. and Shaerya F.: Tuberculosis in active dialysis patients in Jeddah.Am. J. Nephrol., 1999; 19 (1): 34-37.

10. Simon J. Q., Mark A.W., Bell christine E., Mutchinson Alastair J. and Gokal Ram: Peritoneal Tuberculosis in patients receiving continuous ambulatory peritoreal dialysis. Nephrol-Dialysis-Transp lantation, 2001; $16: 1624-1027$.

11. Smirmoff M., Patt C., Seckler B and Adler J.J.: Tuberculin and anergy skin testing of patients 


\section{Mona Hosny}

receiving long term Hemodialysis. Chest, 1998; Jan. 113 (1) : 25 - 27.

12. Portillo-Gomey L., Morris S.L. and Panduro A.: Rapid and efficient detection of extrapul monary Tuberculosis by PCR analysis.Int. J. Tuber. Lung. Dis, 2000; Apr 4(4): 361-370.

13. Waeitje K.F., Mathew A., Rothstein M., Saler S. and Fraser V.J.: Tuberculosis infection and anergy in Hemodialysis patients. Am. J. Kidney Dis., 1998; May 31(5): 848-852 .

14. Wang S. X. and Tay L.: Evaluation of three Nucleic Acid Amplification Methods for Direct
Detectrion of Mycobacterium

Tuberculosis Complex in respiratory specimens. Journal of Clinical Microbiology, 1999; June: 1932-1934.

15. Wols Ka - Gosz Ka L., Nowak A., Galinski J. and Slominiski J.M.: Zastosowanie lancuchowej reakyi polimerazy (PCR) do wg Krywania Mycobacterium Tuberc ulosis complex w materialachod chorych .(Use of Polymerase chain reaction) $[\mathrm{PCR}]$ for detection of mycobacterium Tuberculosis com plex from patient materials. Pneumonol-Alergol-Pol., 1998; 66 (1-2) : 31-37. 


\section{Prevalence of Renal Tuberculosis in Patients}

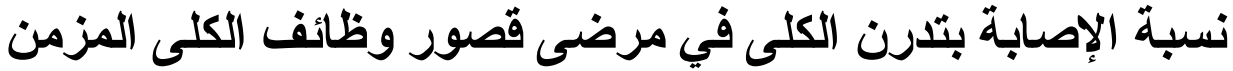

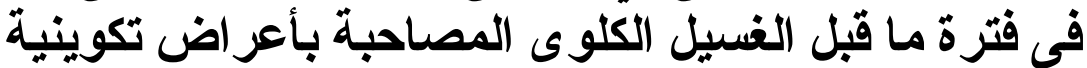

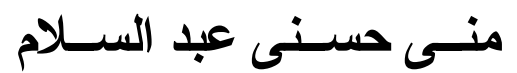

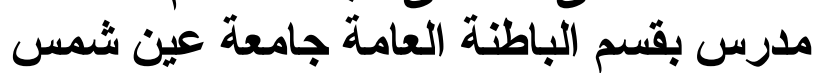

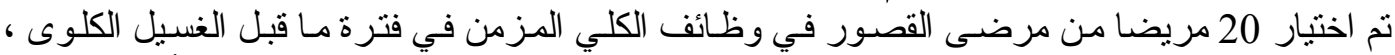

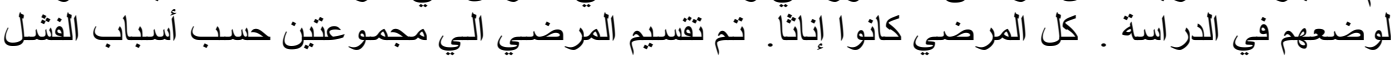

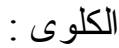

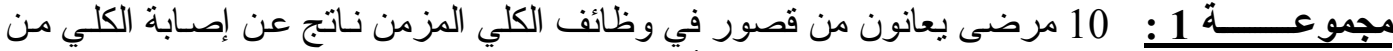

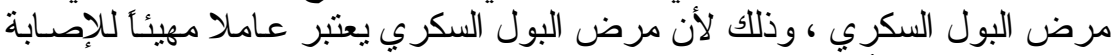

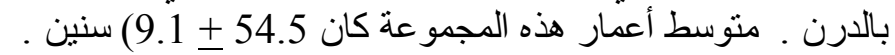

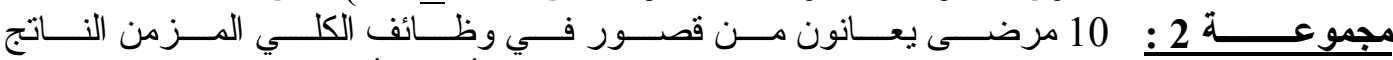

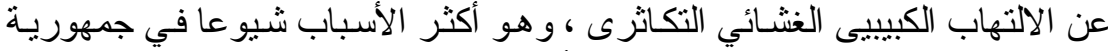

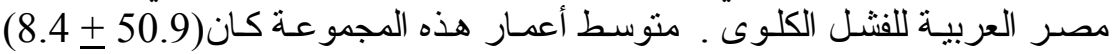

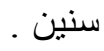

هاتان المجمو عتان تم مقارنتهما بمجمو عة ثالثة تتكون من 10 أثخاص طبيعيين كمجمو عة ضابطة الثنان

ـ أعر اض التكوينية و أعر اض الجهاز التتاسلي و البولي كانتا مرشدتان في اختيار المرضي المشمولين

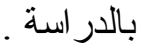
لكل المرضى تم عمل الآتى : بلـي

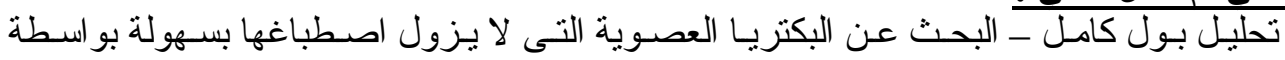

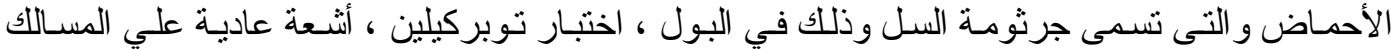

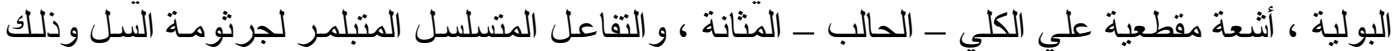

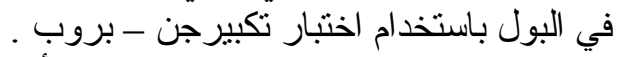

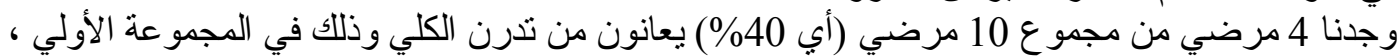

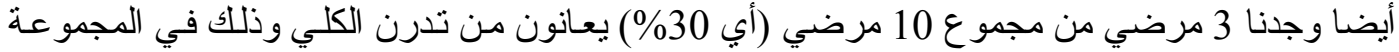
الثانية وذلك باستخدام الاختبار ات المعملية ووسائل النتخيص الإنشعاعي السابقة.

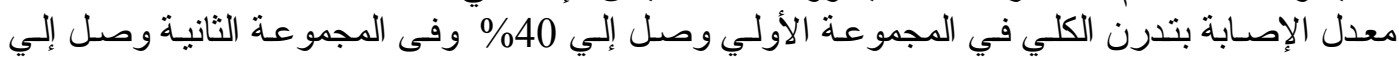

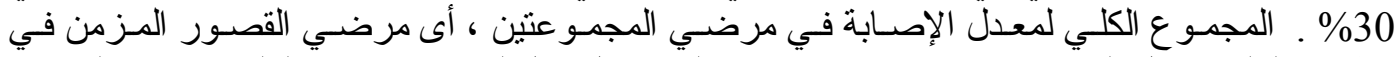

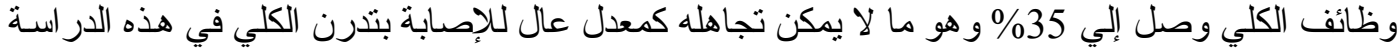

ونحن نستتتج من هذه الدر اسـة أن مرضـي البول السكري يعتبر عامل مخاطرة بالنسبة للإصـابة بتدرن

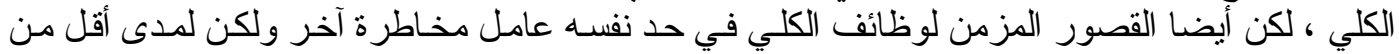

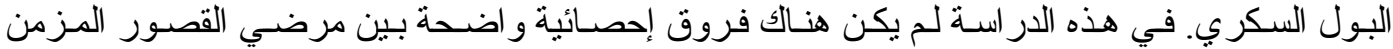

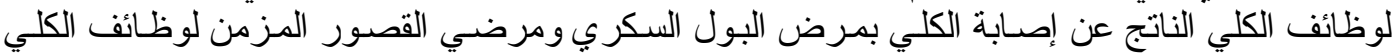

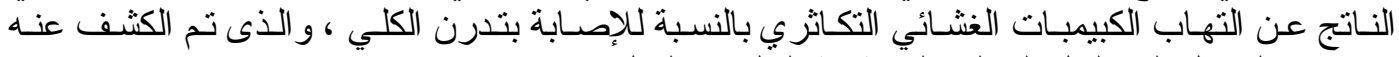

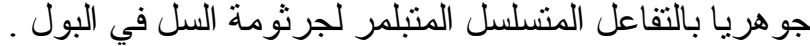

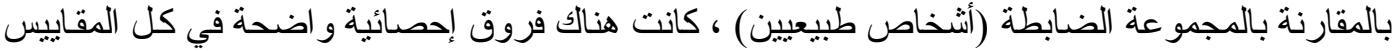

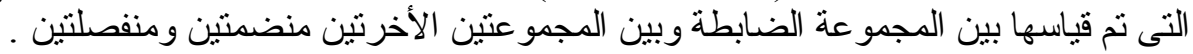

